\title{
Sosyonomik Yaklaşım Kapsamında Uluslararası Ticaret ve Finansal Piyasalar Arasındaki İlişki: Eşbüiünleşme ve Nedensellik Analizi
}

\section{The Relationship Between International Trade and Financial Markets in the Scope of Socionomics Approach: The Analysis of Cointegration and Causality}

\author{
Ayberk Şeker ${ }^{\text {a* }}$ \\ ${ }^{a}$ Dr. Öğr. Üyesi, Bursa Teknik Üniversitesi, İnsan ve Toplum Bilimleri Fakültesi, Uluslararası Ticaret ve Lojistik Bölümü, 16320, Bursa/Türkiye. \\ ORCID: 0000-0001-7750-6286
}

\section{MAKALE BİLGİSİ \\ Makale Geçmişi: \\ Başvuru tarihi: 01 Şubat 2019 \\ Düzeltme tarihi: 09 Temmuz 2019 \\ Kabul tarihi: 17 Temmuz 2019}

\section{Anahtar Kelimeler:}

Uluslararası Ticaret

Finansal Piyasalar

Sosyonomi

ARDL Sinır Testi

Granger Nedensellik Testi

\section{A R T I CLE INFO}

\section{Article history:}

Received 01 February 2019

Received in revised form 09 July 2019

Accepted 17 July 2019

\section{Keywords:}

International Trade

Financial Markets

Socionomics

ARDL Bound Test

Granger Causality Test
ÖZ

Bu çalışma ile sosyonomik yaklaşım kapsamında Türkiye'nin ABD, Almanya, İngiltere ve Fransa'ya gerçekleştirdiği ihracat ile aynı ülkelerin ekonomik olarak sosyal ruh hallerinin göstergesi olan finansal piyasaları arasındaki ilişki analiz edilmektedir. Çalışmada, 1996 ve 2018 y1lları arasındaki dönemi kapsayan aylık ihracat verileri ile aylık finansal piyasa getirileri kullanılmıştır. ARDL sınır testi sonucunda, Türkiye'nin ABD, Almanya, İngiltere ve Fransa'ya gerçekleştirdiği ihracat ile bu ülkelerin finansal piyasaları arasında eşbütünleşme ilişkisi olduğu görülmüştür. Granger Nedensellik analizi sonucunda, ABD ve Almanya finansal piyasalarından (Dow Jones-Dax) Türkiye'nin ABD'ye ve Almanya'ya gerçekleştirdiği ihracata doğru ve Türkiye'nin İngiltere'ye gerçekleştirdiği ihracattan İngiltere finansal piyasalarına (FTSE100) doğru tek yönlü bir nedensellik ilişkisi tespit edilmiştir.

\section{Giris}

Uluslararası ekonomide son yirmi yıl içerisinde birçok önemli finansal ve ekonomik olay meydana gelmiştir. Piyasalarda oluşan bu olayların gerçekleşmesinde dayandığı ekonomik gerekçeler kadar ekonomik olmayan ve insanların sosyal ruh hallerine bağlı olarak meydana gelen olaylar da bulunmaktadır. Özellikle son yıllarda ortaya koyulan sosyonomi yaklaşımıyla, gerçekleşen ekonomik ve finansal olaylar insanların ruh hallerine bağlı olarak açıklanmaya çalışılmaktadır.

Ekonomide meydana gelen finansal olayları ekonomik gerekçelere dayandırarak açıklama yoluna giden Fama, piyasalardaki fiyatların mevcut tüm bilgiyi yansıttığını savunmaktadır. Piyasaya dair mevcut tüm bilgilerin yansitılması durumu ise etkin sermaye piyasası olarak nitelendirilmektedir. Fama ileri sürdüğü etkin piyasa hipotezini üç forma ayırmıştır. Bunlardan ilki, zayıf formda

*Sorumlu yazar/Corresponding author

e-posta: ayberk.seker@btu.edu.tr 
etkin piyasa hipotezidir. Zayıf formda etkin piyasalarda, geçmiş fiyat hareketlerine bakarak gelecekteki fiyatlar hakkında tahmin üretilmektedir. Buna ek olarak fiyat değişimlerinin bağımsız ve tesadüfi olarak gerçekleştiği kabul edilmektedir. İkincisi, yarı-güçlü formda etkin piyasalardır. $\mathrm{Bu}$ formda ise, eldeki geçmiş verilere ek olarak kamusal bilgilerin de bulunduğu bilgi seti söz konusudur. Üçüncü form ise güçlü formda etkin piyasalardır. $\mathrm{Bu}$ formda ise, fiyatlar mevcut olan tüm bilgileri yansitmaktadır. Piyasalarda katılımcılar arasında herhangi bir üstünlük olmamakla birlikte, piyasa etkinliği maksimum düzeydedir (Fama, 1969).

Fama'nın etkin piyasa formlarını rassal yürüyüş kuramına dayanarak ortaya koymaktadır. Rassal yürüyüş kuramına göre, piyasadaki fiyat değişimlerinin seri olarak birbirinden bağımsız bir şekilde gerçekleştiği ve dolayısıyla piyasadaki fiyatların gelecekteki fiyatların yönü için yeterli gösterge olmadığı ileri sürülmektedir (Fama, 1965: 56). Ancak, son yıllarda gerçekleşen ekonomik olayların gelişiminde özellikle bireylerin rasyonaliteden uzaklaşmaları sonucunda davranışsal ekonomi (finans) yaklaşımları önem kazanmıştır. Dolayısıyla, rassal yürüyüş kuramında ileri sürüldüğü üzere ekonomik olayların gelişimi rasyonellikten uzaklaşmıştır.

Bireylerin ekonomik yapı içerisinde kişisel duygu ve güdülerine dayanarak gerçekleştirdikleri ekonomik eylemleri davranışsal olarak inceleyen birçok yaklaşım bulunmaktadır. Bireylerin meraklarını ve trendleri inceleyen Sosyal Psikolojik Yaklaşım, bilgi akışı ve geribildirimleri inceleyen Bilgi Teorisi ve Sibernetik Yaklaşım, Etolojik Yaklaşım, Ekonofizik Yaklaşım ve Sosyonomik Yaklaşım bu yaklaşımlar arasında yer almaktadır (Parker ve Prechter, 2005).

Sosyonomik yaklaşıma göre, bilinçsiz duygusal dürtülerin psikolojik kaynaklarına dayalı bir biyolojik yapı olarak insanlar, finansal piyasa katılımcıları ile etkileşim içerisindedir. $\mathrm{Bu}$ doğrultuda, bilgi eksikliği ya da mantıksızlık durumunda insanların titiz bir şekilde olayları değerlendirmek yerine başkalarının davranışlarına bağımlı kalarak daha kolay bir yolu seçmektedirler (Prechter, 2001: 120-121). Bununla birlikte, R. N. Elliot insan duygularının ritmik olduğunu ve iş hayatı, ticari hayat ya da siyasi hayat gibi tüm aktiviteleri etkilediğini ifade etmektedir. İnsanların olumlu sosyal ruh haline sahip olmaları durumunda mutlu, birleştirici, yapıcı, iyimser, yardımsever, özgürlükçü vb. yaklaşımlara sahip olacağı; olumsuz ruh halinde ise dışlayıcı, mutsuz, sinirli, korku içinde, endişeli, kötümser ve kısıtlayııı bir anlayış içerisinde olacağı belirtilmektedir (Prechter, 2009: 228). Sosyal ruh hali döngüsünde toplumda oluşan duygusal özellikler Şekil 1 ve Tablo 1'de ayrıntılı olarak gösterilmiştir.

Şekil1. Sosyal Ruh Hali Döngüsü ve Aşamaları

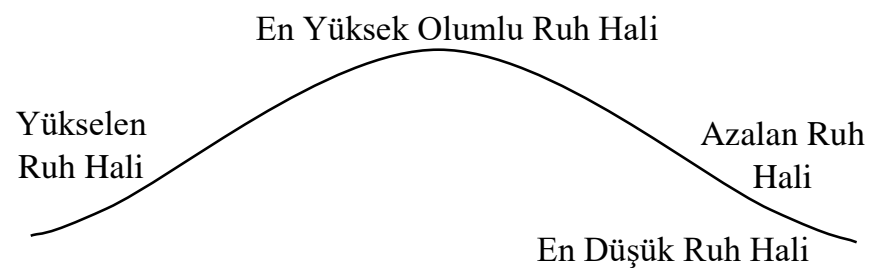

Tablo 1. Sosyal Ruh Hali Döngüsündeki Oluşan Duygusal Özellikler

Sosyal Ruh Hali Döngüsündeki Aşamalara Göre Gerçekleșen Duygusal Özellikler

\begin{tabular}{cccc}
\hline $\begin{array}{c}\text { Yükselen } \\
\text { Ruh Hali }\end{array}$ & $\begin{array}{c}\text { En Yüksek } \\
\text { Olumlu Ruh } \\
\text { Hali }\end{array}$ & $\begin{array}{c}\text { Azalan Ruh } \\
\text { Hali }\end{array}$ & $\begin{array}{c}\text { En Düşük } \\
\text { Ruh Hali }\end{array}$ \\
\hline İyimserlik & Aşırı Güven & Karamsarlık & Korku \\
\hline Mutluluk & Zindelik & Üzgün & Bunalma \\
\hline Cömert & Aşırılık & Muhafazakâr & Cimrilik \\
\hline Kapsayıcı & Çelişkili & Dışlayıcı & Ayrımcı \\
\hline Destekleyici & Nezaket & Savunmacı & Muhalif \\
\hline Umutlu & Güven & Şüpheci & Güvensizlik \\
\hline
\end{tabular}

Kaynak: Nofsinger, 2005.

Sosyonomik yaklaşım, belirsizlik kapsamında insanların homojen gruplar halinde geliştikleri, içsel dinamiklere sahip oldukları ve rasyonel olmayan bir davranış modelini açıklamaktadır. $\mathrm{Bu}$ yaklaşım, modern bir perspektif oluşturmak adına finansal davranışların karmaşık gerçekliğini ele almaktadır. Sosyonomikparadigma, günümüzde sosyal bilimlerde çoğu teorinin temelinde yatan insan davranışlarının rasyonel tercihler modeline karşı ortaya koyulmuştur.

Parker ve Prechter (2005), sosyonominin temel kuramsal ilkelerini çalışmalarında ortaya koymuştur. $\mathrm{Bu}$ doğrultuda sosyonomi, paylaşılan bilinçsiz dürtüler sosyal ruh eğilimleri olarak meydana gelen kitlesel psikolojik dinamiklerin ortaya çıkmasına yol açmaktadır. Bununla birlikte, ortaya çıkan sosyal ruh eğilimleri düzenlidir ve tahmin edilebilme olasılığı bulunmaktadır. İnsanların davranış kalıpları, dışsal nedenlere bağlı olarak değil, içsel süreçlere bağlı olarak oluşmaktadır. Ayrıca, sosyal ruh eğilimleri, sosyal eylemlerin altında yatan nedenler olarak karşımıza çıkmaktadır (Parker ve Prechter, 2005).

\section{Finansal Piyasalar ve Uluslararası Ticaret İlişkisi}

Finansal piyasalar, uluslararası ekonomide toplumların ve ülkelerin ekonomik durumlarını ortaya koyan önemli bir platformdur. İnsanların piyasadaki finansal araçları kullanarak gerçekleştirdikleri yatırımlar, ülke ekonomisindeki gidişat hakkında bilgiler içermektedir. $\mathrm{Bu}$ nedenle, ekonomideki olumlu veya olumsuz havayı ülkelerin finansal piyasalarına bakılarak görülebilmektedir.

20. yüzyıl ile birlikte uluslararası ekonomide ortaya çıkan küreselleşme olgusu ile birlikte üretim ve tüketimlerin ulusal boyutlardan küresel boyutlara taşınması söz konusu olmuştur. Böylelikle ülke ekonomileri arasında küresel finansal ve ekonomik ağlar oluşmaya başlamıştır (Balkanlı, 2002: 14). Bu doğrultuda, küreselleşme ile birlikte oluşan finansal ve ekonomik liberalizasyon ülkeler arasındaki finansal ve ticari yatırımların yükselmesini sağlamıştır.

\subsection{Finansal Piyasalar ve Sosyonomi}

Finansal piyasalarda fiyatların fraktal bir yapı içerisinde olduğu ve belirsiz çeşitlilikler gösterdiği görülmektedir. Elliot, finansal piyasaların davranışları üzerine gerçekleştirdiği araştırmalar sonucunda borsa fiyatlarının 
sayısal ifadelerinde özel kalıplara sahip fraktal yapılar bulunduğunu belirtmiştir. Prechter (2002) bu durumu güçlü fraktal yapı olarak tanımlamaktadır. Bu tanıma göre güçlü fraktal yapılar yaşam formlarına nüfuz etmektedir. Bu doğrultuda, finansal piyasalar insanların sosyal etkileşimlerinin bir ürünü olması nedeniyle yaşam formları içerisinde yer almaktadır (Prechter, 2002: 23).

Finansal piyasalardaki gelişmeleri yalnızca ekonomik yaklaşımlara göre açıklamaya çalışmak ve sosyal ve ekonomik değişimleri sadece diş etkenleri göz önüne alarak değerlendirmek gerçeği yansıtmamaktadır. Çünkü toplumun sosyal ruh hali kendi içsel ritmine göre oluşmaktadır. Bu doğrultuda, insanların anlam atfettikleri ve yorumladıkları dış olaylar ekonomiye etki etmektedir. Fakat yorumlanan bu diş olay, belirli bir dönemdeki sosyal ruh haline ve o dönemde toplumdaki olumlu veya olumsuz havanın derecesine bağlı olarak yorumlanmaktadır (Green, 2002; Atwater, 2013). Shiller (1984) bu durumu, finansal piyasalardaki fiyatların sosyal hareketlerden etkilendiğini belirterek desteklemektedir.

Finans literatüründe etkin piyasalar hipotezi finansal piyasalardaki fiyat değişimlerine geçerli bir açıklama getirmektedir. Bu hipoteze göre, piyasadaki katılımcılar her zaman bilgiye sahip ve rasyonel davranmaktadırlar. Ancak, etkin piyasalar hipotezi finansal piyasalarda borsa balonunun oluşmasına yol açan rasyonel olmayan tercihleri açıklamada ve hesap etmede eksik kalmaktadır. Bu durum, insanların ve toplumun duygusal ve dürtüsel boyutlarını dikkate almayan tek boyutlu anlayışın bir sonucu olmaktadır (Green, 2002).

Finansal piyasalar birbirleriyle ve toplumla etkileşim içerisinde olan birçok katılımcıdan meydana gelmektedir. Katılımciların olumlu ya da olumsuz tutumlarının seviyesi toplumun yatırım kararlarını etkilemektedir. Menkul kıymet alımı veya satımı ile ilgili yatırım kararları katılımcıların sosyal ruh hali ve beklentilerine göre şekillenmektedir. Rasyonel beklentiler modeli, yatırımcıların beklenti ve yatırım kararlarını temel analiz ve modern portföy teorisi gibi araçları kullanarak faydalarını maksimize edebilmek amacıyla rasyonel bir şekilde belirlediğini varsaymaktadır (Olson, 2006: 193; Just, 2013: 2). Rasyonel beklentiler modeli yatırımcıların tarafsız ve rasyonel bir şekilde piyasadaki belirsizlikleri bertaraf etmeleri gerektiğini ortaya koymaktadır. Ancak yatırımcılar toplumda hâkim olan sosyal ruh halinden etkilenmekte ve yatırımlarında bu olguyu da göz önünde bulundurarak karar vermektedirler (Nofsinger, 2005: 148).

Neo-klasik finansal ekonomi literatüründe sosyal faktörleri göz ardı ederek genel ekonomik denge üzerinde odaklanılan bir eğilim bulunmaktadır. Ancak ekonomik dinamikler sosyal dinamikleri bir unsuru olarak kabul edilebilmektedir. Sosyonomik yaklaşıma göre, duygular ya da sosyal ruh hali toplumun geneli tarafından paylaşıldığında, toplumdaki iyimserliğin düzeyi fiyatları etkilemekte ve piyasa genelinde çeşitli olaylara yol açabilmektedir (Nofsinger, 2005: 144).

\subsection{Uluslararası Ticaret ve Sosyonomi}

Toplumların sosyal ruh hali küreselleşme ile birlikte yalnızca finansal piyasalarda değil, aynı zamanda ülkelerin uluslararası ticaretlerinde de etkin bir rol oynamaktadır.
Ülkelerin ve toplumların sosyal ruh hallerine bağlı olarak, bazı dönemlerde uluslararası ticarette verimli sonuçların doğduğu bazı dönemlerde de ülkelerin birbirleri ile olan ticaretlerinde kesintiler yaşandığı görülmektedir.

Neo-klasik iktisat yaklaşımına göre ekonomide tercihleriyle yer alan kişilerin rasyonel oldukları kabul edilmektedir. $\mathrm{Bu}$ görüşe göre, toplumdaki bireylerin bütün alternatifler ve fiyatlar hakkinda tam bilgiye sahip oldukları varsayılmaktadır. Bu doğrultuda, kişilerin fayda-maliyet analizleri vasitasıyla kendisi için maksimum düzeyde faydayı sağladığı ve bunun sonucunda da toplumun fayda düzeyinin maksimum düzeye ulaşabileceği kabul edilmektedir (Can Kamber, 2018: 170).Toplumdaki bireylerin tercihleri doğrultusunda, ülkelerin uluslararası ticaretinin de şekillenmesi söz konusu olabilmektedir. Bu noktada Keynes, toplumdaki bireylerin rasyonel kararlar almadığını ve bireylerin tercihleri doğrultusunda yanlışlar yapabilen kişiler olduklarını ileri sürmüştür. Bireylerin alabilecekleri yanlış kararlar ile ekonominin ve piyasaların dengelerini bozabileceğine değinmiştir. Keynes bu iddialarını, bireylerin piyasa ve tercihler konusunda tam bilgiye sahip olmadıklarını, bu nedenle yanlış kararlar alabileceklerini, bireylerin kararlarını her zaman dengesini sağlamış bir piyasada vermediklerini belirtmektedir. Keynes, bireylerin tüketim eğilimi ve hayvani içgüdüleri gibi kavramları literatüre ekleyerek psikolojik yaklaşımları iktisat literatürüne katmıştır. Keynes, bireylerin iktisadi kararlarının para kazanma hırsını ortaya koyan hayvani içgüdüler vasıtasıyla alındığını ileri sürmüştür (Galeotti ve Karakostas, 2010: 4).

Keynes'in literatüre katmış olduğu önemli kavramlardan bir diğeri de belirsizlik kavramıdır. Neoklasik anlayışa göre, ekonomik faaliyetler kesinlik içerisinde gerçekleşirken; Keynes, ekonomik faaliyetlerin geleceğinin belirsizlik durumu içerdiğini ifade etmiştir. Firmaların tahminleri ve beklentileri doğrultusunda mal ve hizmet üretimi gerçekleştirmesi, gelecek tahminlerine göre gerçekleşmektedir. $\mathrm{Bu}$ durum geleceğin belirsizliğini göstermektedir (Turan ve Öztürk, 2016: 260). Uluslararası ticarette ülkeler ve firmalar üretimlerini gerçekleştirmekte ve bu ürünleri diğer ülke pazarlarına sunmayı hedeflemektedirler. Bu noktada, belirsizlik ortamında karşı ülkelerin finansal ve ekonomik durumları önemli göstergeler olabilmektedir.

Uluslararası ticarette toplumların sosyal ruh hali kadar ülkelerin uluslararası ekonomide oluşturdukları küresel sosyal ruh hali de önem arz etmektedir. Küresel sosyal ruh hali, uluslararası platformda meydana gelen olaylar vasıtasıyla "küresel" ve "katılımcı" olabildiği gibi, "bölgesel" ve "ayrımcı" da olabilmektedir. Uluslararası ticarette küresel sosyal ruh halinin olumlu olması halinde serbest ticaret ortamı oluşmakta iken, küresel sosyal ruh halinin olumsuz bir hava içermesi durumunda ülkeler korumacı ticaret anlayışını benimsemektedirler (Casti, 2010: 122).

Ülkeler arasında meydana gelen politik meseleler, ticaret engelleri gibi olumsuz olaylar küresel ruh halini negatif yönde etkilemekte ve ülkelerin birbirleri arasındaki ticaretleri olumsuz olarak etkilenmektedir. Bunun aksine, uluslararası platformda oluşan olumsuz koşulların göz ardı edilmesi veya ülkeler arasında olumlu yaklaşımlar meydana 
geldiğinde uluslararası ticaretin bu durumdan olumlu etkilenmesi söz konusu olmaktadır.

\section{Literatür Taraması}

Sosyonomik yaklaşım ile ülkelerin finansal piyasalarında ve uluslararası ticaretlerinde meydana gelen olayları inceleyen çalışmalar literatürde bulunmakla birlikte, bu alanda çok yoğun bir çalışma bulunmamaktadır. Sosyonomi ile ilgili literatür taranırken, Türkiye'de ortaya koyulmuş herhangi bir çalışmaya rastlanılmamıştır.

Sosyonomik yaklaşım ile ilgili literatürde görülen ilk çalışma Shiller (1984) tarafindan gerçekleştirilmiştir. Çalışmada, ARIMA modelleri kullanılarak zaman serisi analizleri gerçekleştirilmiştir. Analizler sonucunda, toplam reel hisse senedi fiyatları ve toplam reel temettü tutarları arasında zaman içerisinde yüksek ilişki bulunduğu ortaya koyulmuştur. 1926 ve 1983 yılları arasında, yıllık S\&P hisse senedi fiyat endeksi ile yıllık reel temettü serisi arasındaki korelasyon 0.91 , yıllık reel getiri arasındaki korelasyon 0.75 olarak hesaplanmıştır. Çalışmanın sonucunda, toplumsal olayların, trendlerin ve tercihlerin spekülatif varlık fiyat hareketlerinin baskın nedeni olduğu ortaya koyulmuştur.

Prechter (2001) çalışmasında, insan gütme davranışlarının bireylerdeki başkalarının davranışlarından elde edilen sinyallere yanıt olarak dürtüsel zihinsel etkinlikten doğduğu ortaya koyulmaktadır. İnsanların duygularının ağır bastığı durumlarda, insanlarda oluşan dürtülerin akılcı ve rasyonel davranışlardan daha etkin olduğu belirtilmektedir. Ancak, dürtüler sonucunda insanların gütme davranışlarının ilkel şartlar için uygun olmasına rağmen finansal konularda bu davranışın uygun olmadığ 1 ifade edilmektedir.

Nofsinger (2005), toplumdaki iyimser veya kötümser havanın düzeyinin finansal katılımcıların davranışları tarafindan yansitıldığını ileri sürmektedir. Ortaya koyulan bu hipotezin sonuçlarından ilki olarak, sosyal ruh halinin tüketiciler, yatırımcılar ve şirket yöneticileri tarafından alının kararların belirleyicisi olduğu ortaya koyulmaktadır. İkinci olarak, finansal piyasalardaki işlemlerin etkin ve duygusal doğası nedeniyle finansal piyasaların kendisinin doğrudan bir ölçü ve sosyal ruh halinin göstergesi olduğu belirtilmektedir. Son olarak ise sosyal ruh halinin finansal piyasaların gelecekteki finansal ve ekonomik durumların tahmininde yardımcı olduğu ifade edilmektedir.

Parker ve Prechter (2005) çalışmalarında finansal piyasalar ve ekonomideki önemli kavramlardan biri olan gütme davranışını ele almaktadırlar. Çalışmada gütme kavramına ilişkin teorik yaklaşımları özetlemektedir. Çalışma kapsamında ele alınan yaklaşımlar; sosyal psikolojik yaklaşım, bilgi teorisi ve sibernetik yaklaşım, etolojik yaklaşım, ekonofizik yaklaşım ve sosyonomik yaklaşımdır.

Shiv vd. (2005) yatırım davranışları ve insan duygularını ele aldıkları çalışmalarında, normal yatırımcı ve kontrol hastalarının yatırımlarında kazanç sağladıkları ya da kayıp yaşadıklarında muhafazakâr bir davranış sergiledikleri ve bir sonraki dönemde yatırım yapma konusunda daha az istekli oldukları ortaya koyulmaktadır.

Olson (2006) çalışmasında insan duygularının finansal davranışlar üzerinde etkili olduğunu belirtmektedir. Sosyal ruh halinin finansal ve toplumsal trendlerin oluşumunda birincil neden olduğu ifade edilmektedir. Çalışmada, sosyal ruh halinin bilimsel temelinin oluşturulması için kişiliğin ruh hali ile ilişkili psikolojik araştırmalar gözden geçirilmektedir. Çalışmada kişilik boyutları ve fonksiyonları incelenmiş, finansal ve ekonomik davranışlar üzerindeki etkileri ele alınmıştır. Çalışma sonucunda, sosyal ruh halinin insan doğasına temel olan ve finansal sonuçları etkileyen ampirik olarak kurulan kişilik boyutlarında yer ettiği ortaya koyulmuştur.

Parker ve Prechter (2006) çalışmalarında sosyonominin sosyal ruh hali ve sosyal eylemler arasindaki nedensel ilişkiyi tanımlayan sosyal davranış teorisi olduğunu belirtmektedirler. Çalışmada, sosyonomik teorideki bilinçsiz davranışlar ve sosyal davranışların rasyonalitesi arasındaki benzer fikirler araştırılmaktadır.

Parker (2006) çalışmasında ekonomi alanında metodolojik bireycilik ve metodolojik doğa bütünlügünü bir araya getirmeyi amaçlamıştır. Prechter tarafından ortaya koyulan sosyonominin yeni paradigmasının, metodolojik bireycilik ve metodolojik doğa bütünlüğünün teorik sentezinden oluştuğunu belirtmektedir. Çalışmada ekonomik teorinin tarihi analiz edilmiştir. Analizlerin sonucunda, olumlu sosyal ruh hali döneminin metodolojik bireycilikle, olumsuz ruh hali döneminin ise metodolojik doğa bütünlüğü ile ilişkili olduğu ortaya koyulmuştur.

Prechter ve Parker (2007) çalışmalarında neo-klasik ekonominin finansal modeller için yeterli açıklamalar getiremediğini ve ekonomik ve finansal davranışların motivasyon dinamiklerine sahip oldukların belirtmektedirler. Sosyonomik teorinin ekonomi ve finansin ürettiği farklı davranışlar arasındaki bağlamsal farklılıklar ortaya koyduğu, ancak etkin piyasalar hipotezinin bu farklılıkları açıklamada yeterli olmadığını ifade etmektedirler.

Mitroi ve Oproiu (2014) çalışmalarında yatırımcıların psikolojik eğilimlerinin uzun vadede yatırım performanslarının ortalama düzeyde eğilim göstermesine yol açacağı ve trendi takip ederek finansal piyasa katılımcılarının kayda değer bir sürdürülebilir fayda sağlayamayacakları ortaya koyulmaktadır. Çalışmada analiz yöntemi olarak ARMA, ARCH ve GARCH ekonometrik modelleri kullanılmıştır. Analizler sonucunda davranışsal önyarg1 ve etkilerin bir yansıması olarak, istatistiki göstergelerin piyasaların rassal yürüyüşe sahip olmadığı sonucunu desteklediğini tespit etmiştirler.

\section{Ampirik Analiz}

Bu çalışmada Türkiye'nin uluslararası ticaretinde önemli paya sahip ABD, Almanya, İngiltere ve Fransa'ya gerçekleştirdiği ihracat ile aynı ülkelerin finansal piyasaları arasındaki kısa ve uzun dönemli ilişki değerlendirilmiştir. Kısa ve uzun dönemli ilişkileri analiz etmek için, ilk olarak tanımlayıcı istatistikler hesaplanmış, değişkenler arasındaki korelasyon ilişkisi değerlendirilmiştir. Sonraki aşamada değişkenler arasındaki ilişkileri değerlendirebilmek için serilerin durağanlık testleri yapılmış ve ARDL sınır testi vasıtasıyla değişkenler arasındaki eşbütünleşme ilişkisi test edilmiştir. Daha sonra Türkiye'nin bu ülkelere gerçekleştirdiği ihracat ile aynı ülkelerin finansal piyasalar arasındaki nedensellik ilişkisini analiz etmek amacıyla Granger nedensellik testi gerçekleştirilmiştir. 
Korelasyon analizi ile değişkenler arasında ilişki bulunup bulunmadığı ile ilgili bilgi edinilmekle beraber, değişkenler arasındaki ilişkinin yönü veya nedensellik ilişkisi hususunda herhangi bir bilgi elde edilememektedir (Gujarati, 2004: 696). Değişkenler arasındaki eşbütünleşme ilişkisi her iki değişkenin de uzun vadede birlikte hareket ettiklerini göstermektedir. Eşbütünleşme analizleri değişkenlerin durağanlığının test edilmesinden sonra gerçekleştirilmektedir.

\subsection{Tanımlayıc1 İstatistikler ve Veri Seti}

Çalışma kapsamında kullanılan veri setlerinden Türkiye'nin ABD, Almanya, İngiltere ve Fransa'ya gerçekleştirmiş olduğu ihracata ilişkin veriler TÜİK(Türkiye İstatistik Kurumu)'ten elde edilmiştir. ABD, Almanya, İngiltere ve Fransa'nın finansal piyasalarına ilişkin veriler ise Yahoo Finance veri tabanından temin edilmiştir. Çalışma kapsamında kullanılan değişkenler ve değişkenlere ilişkin açıklamalar aşağıdaki gibidir;

DİHRABD: Türkiye'nin ABD’ye gerçekleştirdiği ihracatın aylık değişim oranı,

DİHRALM: Türkiye'nin Almanya'ya gerçekleştirdiği ihracatın aylık değişim oranı,

DİHRING: Türkiye'nin İngiltere'ye gerçekleştirdiği ihracatın aylık değişim oranı,

DİHRFRA: Türkiye'nin Fransa'ya gerçekleştirdiği ihracatın aylık değişim oranı,
GDJ: Dow Jones Endeksi aylık getiri oranı,

GDAX: DAX endeksi aylık getiri oranı,

GFTSE: FTSE endeksi aylık getiri oranı,

GCAC40: CAC40 Endeksi aylık getiri oranı.

Türkiye'nin ticaretinde önemli paya sahip olan ABD, İngiltere, Almanya ve Fransa ile gerçekleştirilen ihracat ve bu ülkelerin finansal piyasaları arasındaki ilişkiyi test etmeden önce, çalışma kapsamındaki değişkenlere ait tanımlayıcı istatistikler incelenmiş ve elde edilen bulgular Tablo 2' de sunulmuştur. Elde edilen bulgulara göre; aylık veriler bazında 1996-2018 döneminde Türkiye'den ilgili ülkelere gerçekleşen ortalama ihracat değişim oranları sirasiyla 0.0201 (ABD), 0.0123 (ALM), 0,0199 (ING) ve 0,0179 (FRA) iken; bu ülkelerin finansal piyasalarının aylık ortalama getirileri 0,0056 (DJONES), 0,0056 (DAX), 0,0024 (FTSE100) ve 0,0034 (CAC40) olarak gerçekleşmiştir. Türkiye'den ABD, Almanya, İngiltere ve Fransa'ya gerçekleşen ihracatın standart sapmasının az olması bu değişkenlerin oynaklıklarının düşük olduğunu göstermektedir. İhracat yapılan ülkelerin finansal piyasalarının oynaklıklarını incelediğimizde, tüm piyasalarda orta düzeyde bir sapma görülmekte olduğundan oynaklığın yüksek olmadığı görülmektedir. Oynaklığın yüksekliği maksimim ve minimum değerlere bakılarak da görülebilmektedir.

Tablo 2.Değişkenlere Ait Temel İstatistikler

\begin{tabular}{|c|c|c|c|c|c|c|c|c|}
\hline & DİHRABD & DİHRALM & DİHRING & DİHRFRA & GDJ & GDAX & GFTSE & GCAC40 \\
\hline Ortalama & 0.02 & 0.01 & 0.02 & 0.02 & 0.01 & 0.01 & 0.01 & 0.01 \\
\hline Ortanca & 0.01 & 0.02 & 0.02 & 0.01 & 0.01 & 0.01 & 0.01 & 0.01 \\
\hline En Büyük & 0.74 & 0.41 & 0.63 & 0.42 & 0.11 & 0.19 & 0.09 & 0.13 \\
\hline En Küçük & -0.31 & -0.32 & -0.39 & -0.34 & -0.16 & -0.29 & -0.14 & -0.19 \\
\hline S. Sapma & 0.17 & 0.12 & 0.15 & 0.15 & 0.04 & 0.06 & 0.04 & 0.05 \\
\hline Çarpıklık & 0.71 & 0.16 & 0.43 & 0.16 & -0.75 & -0.86 & -0.68 & -0.56 \\
\hline Basıklık & 4.28 & 3.04 & 4.11 & 2.78 & 4.65 & 5.82 & 3.89 & 3.65 \\
\hline Gözlem & 273 & 273 & 273 & 273 & 273 & 273 & 273 & 273 \\
\hline
\end{tabular}

\subsection{Serilerin Durağanlık Analizleri}

Model kapsamında değişkenlerin birbirleri ile uzun vadede hareket edip etmediklerini test etmek amacıyla eşbütünleşme testi gerçekleştirilecektir. Eşbütünleşme testleri gerçekleştirilmeden önce serileri durağanlıkları sinanacak ve serilerin durağanlık dereceleri belirlendikten sonra eşbütünleşme analizine geçilecektir.

Modele dâhil edilen değişkenler arasındaki ilişkinin anlamlı olarak kabul edilebilmesi için tüm değişkenlerin ya kendi düzeylerinde ya da farkları alındıktan sonra aynı düzeyde durağan hale gelmeleri gerekmektedir. Çalışma kapsamında, serilerin durağanlığını analiz edebilmek için Genişletilmiş Dickey-Fuller (ADF) (Dickey ve Fulller, 1979) testi ve Kwiatkowski-Phillips-Schmidt-Shin (KPSS) (Kwiatkowski-Phillips-Schmidt-Shin, 1992) testi kullanılmıştır. Genişletilmiş Dickey-Fuller (ADF) (1) testi ve Kwiatkowski-Phillips-Schmidt-Shin (KPSS) (2) testi sırasıyla aşağıda gösterilen modellere dayanmaktadır;

$$
\begin{gathered}
\Delta y_{t}=\alpha+\theta y_{t-1}+y_{1} \Delta y_{t-1}+\varepsilon_{\mathrm{t}} \\
\hbar=T^{-2} \sum_{t-1}^{T} \frac{s_{t}^{2}}{s^{2}(l)}
\end{gathered}
$$

Tablo 3.ADF Birim Kök Test Sonuçları

\begin{tabular}{ccc}
\hline \multirow{2}{*}{ Değişkenler } & $\begin{array}{c}\text { ADF (Düzey- } \\
\text { Sabit) }\end{array}$ & $\begin{array}{c}\text { ADF (Düzey- } \\
\text { Sabit ve Trend) }\end{array}$ \\
\cline { 2 - 3 } & t-değeri & t-değeri \\
\hline DİHRABD & $-26.622^{* * * *}$ & $-26.571 * * *$ \\
\hline DİHRALM & $-5.1542 * * *$ & $-5.175^{* * *}$ \\
\hline DİHRING & $-16.195 * * *$ & $-16.173 * * *$ \\
\hline DİHRFRA & $-6.005^{* * *}$ & $-6.199 * * *$ \\
\hline GDJ & $-15.941 * * *$ & $-15.911^{* * *}$ \\
\hline GDAX & $-15.409 * * *$ & $-15.393 * * *$ \\
\hline
\end{tabular}




$\begin{array}{lll}\text { GFTSE } & -16.421 * * * & -16.401 * * * \\ \text { GCAC } & -15.068 * * * & -15.091 * * *\end{array}$

Genişletilmiş Dickey-Fuller birim kök testinin sıfır hipotezi "zaman serilerinin durağan olmadıkları (en az bir birim-kök var)" şeklindedir. Tablo 3'te yer alan sonuçlardan da
Not: - ***,** ve * sirası ile $\% 1, \% 5$ ve $\% 10$ seviyesinde anlamlılığ ifade etmektedir.

görüldüğü üzere, seriler düzeylerinde birim kök testine dâhil edildiklerinde tüm değişkenlerin düzeylerinde durağan olduğu görülmektedir.

Tablo 4.KPSS Birim Kök Test Sonuçları

\begin{tabular}{|c|c|c|c|c|}
\hline \multirow{2}{*}{ Değişkenler } & \multicolumn{2}{|c|}{ KPSS (Düzey-Sabit) } & \multicolumn{2}{|c|}{ KPSS (Düzey-Sabit ve Trend) } \\
\hline & İstatistik Değeri & Kritik Değer & İstatistik Değeri & Kritik Değer \\
\hline \multirow{3}{*}{ DİHRABD } & & $10 \%$ Düzeyi - 0.347 & \multirow{3}{*}{$0.039^{\mathrm{d}}$} & $10 \%$ Düzeyi - 0.119 \\
\hline & $0.047^{\mathrm{d}}$ & 5\% Düzeyi - 0.463 & & 5\% Düzeyi - 0.146 \\
\hline & & $1 \%$ Düzeyi -0.739 & & $1 \%$ Düzeyi - 0.216 \\
\hline \multirow{3}{*}{ DİHRALM } & & $10 \%$ Düzeyi - 0.347 & \multirow{3}{*}{$0.068^{\mathrm{d}}$} & $10 \%$ Düzeyi - 0.119 \\
\hline & $0.136^{\mathrm{d}}$ & 5\% Düzeyi - 0.463 & & 5\% Düzeyi - 0.146 \\
\hline & & $1 \%$ Düzeyi -0.739 & & $1 \%$ Düzeyi - 0.216 \\
\hline \multirow{3}{*}{ DİHRING } & & $10 \%$ Düzeyi - 0.347 & \multirow{3}{*}{$0.054^{\mathrm{d}}$} & $10 \%$ Düzeyi - 0.119 \\
\hline & $0.069^{\mathrm{d}}$ & 5\% Düzeyi - 0.463 & & $5 \%$ Düzeyi - 0.146 \\
\hline & & 1\% Düzeyi - 0.739 & & 1\% Düzeyi - 0.216 \\
\hline \multirow{3}{*}{ DİHRFRA } & & $10 \%$ Düzeyi - 0.347 & \multirow{3}{*}{$0.131^{\mathrm{d}}$} & $10 \%$ Düzeyi - 0.119 \\
\hline & $0.289^{\mathrm{d}}$ & 5\% Düzeyi - 0.463 & & $5 \%$ Düzeyi - 0.146 \\
\hline & & $1 \%$ Düzeyi - 0.739 & & $1 \%$ Düzeyi - 0.216 \\
\hline \multirow{3}{*}{ GDJ } & & $10 \%$ Düzeyi - 0.347 & \multirow{3}{*}{$0.101^{\mathrm{d}}$} & $10 \%$ Düzeyi - 0.119 \\
\hline & $0.101^{\mathrm{d}}$ & 5\% Düzeyi - 0.463 & & 5\% Düzeyi - 0.146 \\
\hline & & 1\% Düzeyi - 0.739 & & 1\% Düzeyi - 0.216 \\
\hline \multirow{3}{*}{ GDAX } & & $10 \%$ Düzeyi - 0.347 & \multirow{3}{*}{$0.069^{\mathrm{d}}$} & $10 \%$ Düzeyi - 0.119 \\
\hline & $0.073^{\mathrm{d}}$ & 5\% Düzeyi - 0.463 & & 5\% Düzeyi - 0.146 \\
\hline & & $1 \%$ Düzeyi -0.739 & & $1 \%$ Düzeyi - 0.216 \\
\hline \multirow{3}{*}{ GFTSE } & & $10 \%$ Düzeyi - 0.347 & \multirow{3}{*}{$0.068^{\mathrm{d}}$} & $10 \%$ Düzeyi - 0.119 \\
\hline & $0.072^{\mathrm{d}}$ & 5\% Düzeyi - 0.463 & & $5 \%$ Düzeyi - 0.146 \\
\hline & & 1\% Düzeyi - 0.739 & & 1\% Düzeyi - 0.216 \\
\hline \multirow{3}{*}{ GCAC } & & $10 \%$ Düzeyi - 0.347 & \multirow{3}{*}{$0.098^{\mathrm{d}}$} & $10 \%$ Düzeyi - 0.119 \\
\hline & $0.151^{\mathrm{d}}$ & 5\% Düzeyi - 0.463 & & 5\% Düzeyi - 0.146 \\
\hline & & 1\% Düzeyi - 0.739 & & $1 \%$ Düzeyi -0.216 \\
\hline
\end{tabular}

Not: "d" serilerin, kritik değerlere göre durağan olduğunu ifade etmektedir.

Tablo 4'te Kwiatkowski-Phillips-Schmidt-Shin birim kök testi sonuçları yer almaktadır. Birim kök testi sonuçlarına göre, tüm değiş̧kenlerin düzey değerlerinde durağan olduğu görülmektedir.

\subsection{ARDL Sinır Testi}

Durağan olmayan serilerin analizinde birim kök testlerinin düşük etkiye sahip olması sıkça karşılaşılan sorunlardan biridir. Bu sorunun üstesinden gelebilmek amaciyla, uzun dönemli ilişkilerin test edilmesinde Pesaran ve Shin (1999) ve Pesaran vd. (2001) tarafindan ortaya koyulan ARDL sinır testi tercih edilmektedir. edilmesinde değişkenlerin bütünleşme derecelerinin aynı olması koşulunun bulunmamasıdır. Başka bir ifade ile ARDL sınır testi, bir ekonometrikmodel üzerinde değişkenlerin birinci farkları alındığında I(1) veya düzey değerlerinde $\mathrm{I}(0)$ durağan olmalarına bakılmaksızın uygulanabilmektedir (Pesaran, vd. 2001:290). Ayrıca, ARDL sınır testi değişkenlerin uzun ve kısa dönemli ilişkilerine ilişkin katsayılar eş zamanlı olarak tahmin edilmesine olanak sağlamaktadır.

ARDL sınır testi genel olarak gecikmesi dağıtılmış otoregresif bir modele dayanmaktadır. Modelin genel olarak gösterimi aşağıdaki gibidir;

ARDL sinır testinin tercih edilmesindeki en önemli nokta, değişkenler arasındaki uzun dönemli ilişkinin analiz

$$
\Delta y_{t}=c_{0}+c_{1} t+\pi_{y y} y_{t-1}+\pi_{y x . x} x_{t-1}+\sum_{i=1}^{p-1} \Psi_{i}^{\prime} \Delta z_{t-i}+\omega^{\prime} \Delta x_{t}+\theta w_{t}+u_{t}
$$

En küçük kareler yöntemi vasıtasıyla tahmin gerçekleştirilen denklemde $\mathrm{c}_{0}$ otonom parametreyi, $\mathrm{t}$ trend değişkenini, $\pi$ yy ve $\pi_{\mathrm{yx} . \mathrm{x}}$ uzun dönem çarpanlarını, $\mathrm{w}_{\mathrm{t}}$ tam bağımsız değişkenler vektörünü, ut otokorelasyonsuz hata terimini temsil etmektedir.

ARDL sınır testi gerçekleştirildikten sonra, elde edilen test istatistiğinin üst kritik değerden yüksek olması durumunda eşbütünleşme ilişkisinin bulunduğu sonucuna varılmaktadır.
Test istatistiğinin alt kritik değerden düşük olması halinde ise eşbütünleşme ilişkisinin bulunmadığına karar verilmektedir. Test istatistiğinin üst ve alt kritik değer arasında bir değer alması halinde ise kararsızlık durumu oluşmaktadır.

Gerçekleştirilen birim kök testleri sonrasında bütün değişkenlerin düzeyde durağan olduğu tespit edilmiştir. Başka bir ifade ile değişkenlerin düzeylerinde durağan 
olması, ARDL sınır testinin uygulanması için geçerli bir neden oluşturmaktadır.

Tablo 5.Sınır Testi için Uygun Modelin Belirlenmesi

\begin{tabular}{|c|c|c|c|c|c|c|c|}
\hline \multicolumn{2}{|c|}{ DİHRABD - GDJ } & \multicolumn{2}{|c|}{ DİHRALM - GDAX } & \multicolumn{2}{|c|}{ DİHRİNG - GFTSE } & \multicolumn{2}{|c|}{ DİHRFRA - GCAC } \\
\hline Model & Adj. $\mathbf{R}^{2}$ & Model & Adj. $R^{2}$ & Model & Adj. $R^{2}$ & Model & Adj. $R^{2}$ \\
\hline $\operatorname{ARDL}(12,12)$ & 0.287019 & $\operatorname{ARDL}(12,12)$ & 0.500914 & $\operatorname{ARDL}(12,9)$ & 0.255023 & $\operatorname{ARDL}(12,3)$ & 0.408122 \\
\hline $\operatorname{ARDL}(11,12)$ & 0.283980 & $\operatorname{ARDL}(12,6)$ & 0.499067 & $\operatorname{ARDL}(12,3)$ & 0.255008 & $\operatorname{ARDL}(12,5)$ & 0.406535 \\
\hline $\operatorname{ARDL}(12,3)$ & 0.281908 & ARDL $(12,5)$ & 0.498774 & $\operatorname{ARDL}(12,5)$ & 0.253364 & $\operatorname{ARDL}(12,4)$ & 0.406286 \\
\hline $\operatorname{ARDL}(12,4)$ & 0.279216 & $\operatorname{ARDL}(12,7)$ & 0.497537 & $\operatorname{ARDL}(12,4)$ & 0.252982 & $\operatorname{ARDL}(12,11)$ & 0.405874 \\
\hline $\operatorname{ARDL}(12,6)$ & 0.278840 & ARDL $(12,8)$ & 0.496441 & $\operatorname{ARDL}(12,7)$ & 0.252720 & $\operatorname{ARDL}(12,9)$ & 0.405513 \\
\hline $\operatorname{ARDL}(12,5)$ & 0.278705 & $\operatorname{ARDL}(12,4)$ & 0.495601 & $\operatorname{ARDL}(12,10)$ & 0.251910 & $\operatorname{ARDL}(12,6)$ & 0.404308 \\
\hline $\operatorname{ARDL}(12,7)$ & 0.277539 & $\operatorname{ARDL}(12,9)$ & 0.495305 & $\operatorname{ARDL}(12,8)$ & 0.251591 & $\operatorname{ARDL}(12,8)$ & 0.403938 \\
\hline $\operatorname{ARDL}(12,2)$ & 0.277222 & $\operatorname{ARDL}(12,3)$ & 0.493641 & $\operatorname{ARDL}(12,0)$ & 0.251261 & $\operatorname{ARDL}(12,10)$ & 0.403774 \\
\hline
\end{tabular}

Tablo 5'te ARDL sınır testinin uygulanması için uygun modelin seçilmesi için Düzeltilmiş $\mathrm{R}^{2}$ Kriteri'ne göre hazırlanan tablo ve grafik gösterilmektedir ( He vd., 2017). Tablo 5'ten elde edilen sonuçlara göre; sırasıyla DİHRABD-GDJ, DİHRALM-GDAX,

DİHRİNG-GFTSE ve DİHRFRA-GCAC sınır testi için uygun olan modeller ARDL (12,12), ARDL(12,12), ARDL(12,9) ve $\operatorname{ARDL}(12,3)$ modelleri olduğu tespit edilmiştir.

Tablo 6.ARDL Sinır Testi

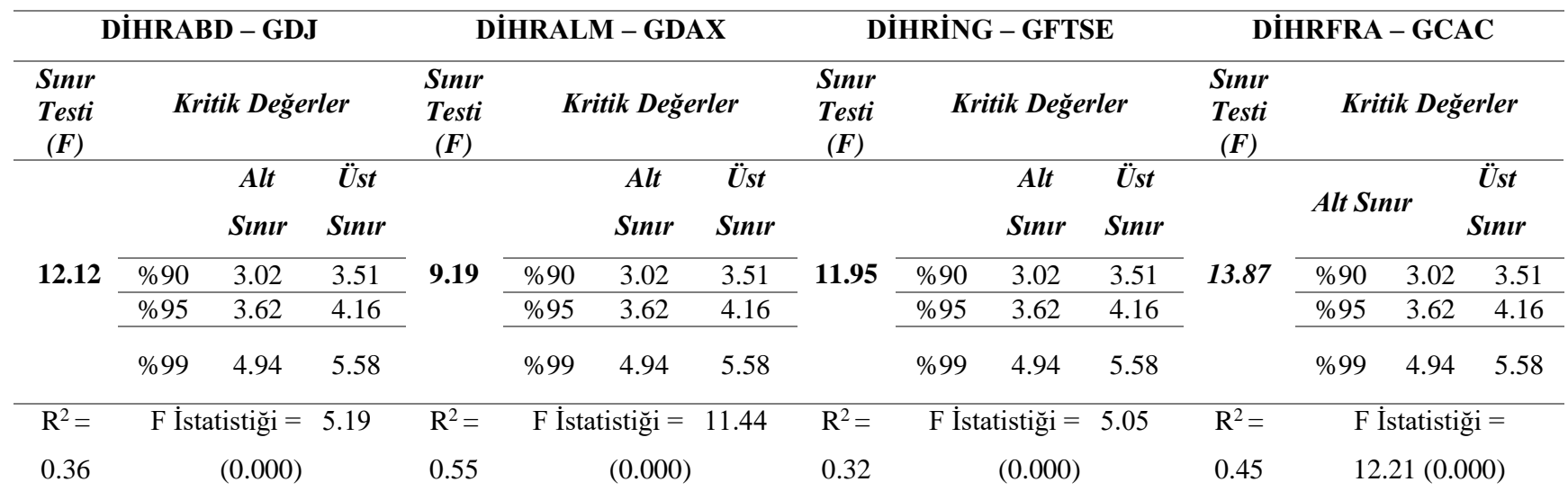

Tablo 6'da yer alan ARDL sınır testi sonucu incelendiğinde, eşbütünleşmenin bulunmadığ $\breve{1}_{1}$ hipotezi tüm modeller için \%99, $\% 95$ ve \%90 güven düzeylerinde reddedildiği görülmektedir. Sirasiyla 12.12, 9.19, 11.95 ve 13.87olarak hesaplanan $F$ istatistiğinin tüm güven düzeylerindeki üst kritik değerlerden

yüksek olması sebebiyle Türkiye'nin ABD, Almanya, İngiltere ve Fransa'ya gerçekleștirdiği ihracatlar ile ABD, Almanya, İngiltere ve Fransa'nın finansal piyasaları arasında eşbütünleşme ilişkisinin bulunduğu tespit edilmiştir.

Tablo 7.ARDL Sınır Testi Uzun Dönem Katsayıları

\begin{tabular}{|c|c|c|c|c|c|}
\hline \multicolumn{3}{|c|}{ DİHRABD - GDJ } & \multicolumn{3}{|c|}{ DİHRALM - GDAX } \\
\hline Değişkenler & Katsayılar & T İst. & Değişkenler & Katsayılar & T İst. \\
\hline GDJ & 0.636 & $2.468 * * *$ & GDAX & 0.144 & 1.076 \\
\hline $\mathrm{C}$ & 0.016 & $4.601 * * *$ & $\mathrm{C}$ & 0.011 & $3.887 * * *$ \\
\hline \multicolumn{3}{|c|}{ DW İstatistiğ $\mathrm{i}=1.992$} & $\mathrm{R}^{2}=0.86$ & \multicolumn{2}{|c|}{ DW İstatistiği $=2.031$} \\
\hline \multicolumn{3}{|c|}{ DIHHRING - GFTSE } & \multicolumn{3}{|c|}{ DİHRFRA - GCAC } \\
\hline Değişkenler & Katsayılar & T İst. & Değişkenler & Katsayılar & T İst. \\
\hline GFTSE & 0.392 & $1.796^{*}$ & GCAC & 0.207 & $2.161 * *$ \\
\hline $\mathrm{C}$ & 0.019 & $6.308 * * *$ & $\mathrm{C}$ & 0.017 & $6.719 * * *$ \\
\hline $\mathrm{R}^{2}=0.75$ & & stiği $=2.026$ & $\mathrm{R}^{2}=0.81$ & & $=2.026$ \\
\hline
\end{tabular}

Not: - ***, ** ve $*$ sirası ile $\% 1, \% 5$ ve $\% 10$ seviyesinde anlamlılı̆̆

Modele dâhil edilen değişkenler arasındaki uzun dönemli ilişkinin tespiti amaciyla oluşturulan ARDL modellerine ait veriler tablo 7'de yer almaktadır. ARDL modellerinin tahmin sonuçlarına dayanılarak hesaplanan uzun dönem katsayı tahminine göre Türkiye'den ABD, İngiltere ve Fransa'ya gerçekleştirilen ihracat ile $A B D$, İngiltere ve Fransa finansal piyasaları arasında uzun dönemli bir ilişkinin bulunduğu tespit edilmiştir. Bu doğrultuda, ABD, İngiltere ve Fransa finansal piyasalarının Türkiye'nin bu ülkelere gerçekleştirdiği ihracatın oluşumunda uzun dönemde etkisinin bulunduğu görülmektedir. Ancak, Türkiye'den Almanya'ya gerçekleştirdiği ihracat ile Almanya finansal piyasaları arasında uzun dönemli bir ilişkinin bulunmadığı tespit edilmiştir. 
Tablo 8.ARDL (12,12), ARDL (12,12), ARDL(12,9) ve ARDL $(12,3)$ Hata Düzeltme Modelleri

\begin{tabular}{|c|c|c|c|c|c|c|c|}
\hline \multicolumn{2}{|c|}{$\begin{array}{c}\text { DİHRABD - GDJ } \\
\text { ARDL (12,12) }\end{array}$} & \multicolumn{2}{|c|}{$\begin{array}{c}\text { DİHRALM - GDAX } \\
\text { ARDL }(\mathbf{1 2 , 1 2 )}\end{array}$} & \multicolumn{2}{|c|}{$\begin{array}{c}\text { DİHRİNG - GFTSE } \\
\text { ARDL }(12,9)\end{array}$} & \multicolumn{2}{|c|}{$\begin{array}{c}\text { DİHRFRA - GCAC } \\
\text { ARDL }(12,3)\end{array}$} \\
\hline Değişkenler & Katsayılar & Değişkenler & Katsayılar & Değişkenler & Katsayılar & Değişkenler & Katsayılar \\
\hline DİHRABD(-1) & $1.308 * * *$ & DİHRALM(-1) & 0.443 & DİHRİNG(-1) & $1.364 * * *$ & DİHRFRA(-1) & $1.218^{* * *}$ \\
\hline DİHRABD(-2) & $1.072 * *$ & DİHRALM(-2) & 0.295 & DİHRİNG(-2) & $1.118 * * *$ & DİHRFRA(-2) & $0.949 * *$ \\
\hline DİHRABD(-3) & $0.891 * *$ & DİHRALM(-3) & 0.216 & DİHRİNG(-3) & $0.918 * *$ & DİHRFRA(-3) & $0.774 * *$ \\
\hline DİHRABD(-4) & $0.676^{*}$ & DİHRALM(-4) & 0.218 & DİHRİNG(-4) & $0.728^{* *}$ & DİHRFRA(-4) & $0.569^{*}$ \\
\hline DİHRABD(-5) & $0.626^{* *}$ & DİHRALM(-5) & 0.279 & DİHRİNG(-5) & $0.601 * *$ & DİHRFRA(-5) & 0.459 \\
\hline DİHRABD(-6) & $0.547^{*}$ & DİHRALM(-6) & 0.357 & DİHRİNG(-6) & $0.482 *$ & DİHRFRA(-6) & $0.425^{*}$ \\
\hline DİHRABD(-7) & 0.272 & DİHRALM(-7) & 0.317 & DİHRİNG(-7) & 0.374 & DİHRFRA(-7) & 0.355 \\
\hline DİHRABD(-8) & 0.108 & DİHRALM(-8) & 0.246 & DİHRİNG(-8) & 0.269 & DİHRFRA(-8) & 0.227 \\
\hline DİHRABD(-9) & 0.046 & DİHRALM(-9) & 0.166 & DİHRİNG(-9) & 0.139 & DİHRFRA(-9) & 0.167 \\
\hline DİHRABD(-10) & 0.019 & DİHRALM(-10) & -0.119 & DİHRİNG(-10) & -0.076 & DİHRFRA(-10) & -0.019 \\
\hline DİHRABD(-11) & -0.089 & DİHRALM(-11) & $-0.295 * * *$ & DİHRİNG(-11) & $-0.213 * * *$ & DİHRFRA(-11) & $-0.231 * * *$ \\
\hline GDJ & -0.047 & GDAX & -0.021 & GFTSE & 0.048 & GCAC & 0.179 \\
\hline GDJ(-1) & $-1.471 * * *$ & $\operatorname{GDAX}(-1)$ & $-0.407 * * *$ & GGTSE(-1) & $-0.969 * * *$ & GCAC(-1) & $-0.334 * *$ \\
\hline GDJ(-2) & $-1.144 * *$ & $\operatorname{GDAX}(-2)$ & $-0.449 * * *$ & GFTSE(-2) & $-0.915^{* *}$ & GCAC(-2) & $-0.288 * *$ \\
\hline GDJ(-3) & $-0.781^{*}$ & GDAX(-3) & $-0.272 * *$ & GFTSE(-3) & -0.526 & ECM(-1) & $-2.747 * * *$ \\
\hline GDJ(-4) & $-0.869 *$ & GDAX(-4) & -0.182 & GFTSE(-4) & -0.421 & & \\
\hline GDJ(-5) & -0.702 & GDAX(-5) & -0.021 & GFTSE(-5) & -0.154 & & \\
\hline GDJ(-6) & -0.497 & $\operatorname{GDAX}(-6)$ & -0.111 & GFTSE(-6) & -0.137 & & \\
\hline GDJ(-7) & $-0.709 *$ & GDAX(-7) & -0.161 & GFTSE(-7) & 0.147 & & \\
\hline GDJ(-8) & $-0.838 * *$ & GDAX(-8) & -0.101 & GFTSE(-8) & 0.316 & & \\
\hline GDJ(-9) & $-0.838 * *$ & GDAX(-9) & -0.171 & ECM(-1) & $-2.815^{* * *}$ & & \\
\hline GDJ(-10) & $-0.854 * *$ & GDAX(-10) & $-0.185^{*}$ & & & & \\
\hline GDJ(-11) & $-0.503 * *$ & $\operatorname{GDAX}(-11)$ & $-0.212 * *$ & & & & \\
\hline ECM(-1) & $-2.868 * * *$ & ECM(-1) & $-2.049 * * *$ & & & & \\
\hline
\end{tabular}

Not: - ***,** ve $*$ sırası ile $\% 1, \% 5$ ve $\% 10$ seviyesinde anlamlılığ

Modeldeki değişkenlerin kısa dönemli ilişkilerine ilişkin sonuçlar tablo 8 'de gösterilmektedir. Dört modelde de hata düzeltme katsayısının (ECM(-1)) istatistiksel olarak anlamlı olduğu görülmektedir. Hata düzeltme katsayısının \%1 düzeyinde anlamlı olması dolayısıyla uyarlanma sürecinin çok hızlı gerçekleştiği tespit edilmiştir. Bununla birlikte, hata düzeltme katsayısının (ECM(-1)) negatif ve anlamlı olması Türkiye'nin ABD, Almanya, İngiltere ve Fransa'ya gerçekleştirdiği ihracat ile aynı ülkelerin finansal piyasalarının eşbütünleşme ilişkisi içerisinde olduğu desteklemektedir.

Hata düzeltme modelinde bulunan hata teriminin negatif ve istatistiksel olarak anlamlı olması, ilgili dönemde meydana gelen sapmaların hızlı bir şekilde düzeltildiğini göstermektedir. Modelde ECM(-1) katsayısı dört model için sirasiyla $-2.868, \quad-2.049, \quad-2.815$ ve -2.747 olarak hesaplanmıştır. Hesaplanan ECM(-1) katsayısı, ilgili dönemde oluşan bir şok veya olağandışı bir etkinin ortaya çıkması halinde bu etkinin bir sonraki yılda hızla giderildiğini ya da düzeltildiğini göstermektedir. Başka bir ifade ile uzun dönem dengesinin hızlı bir şekilde sağlandığı görülmektedir. Ayrıca, ECM(-1) katsayısının 1'den büyük olması sistemin dalgalanma göstererek denge oluşturduğunu göstermekte ve bu dalgalanmalar azalarak uzun dönemdeki dengeyi sağlayacaktır. Bu doğrultuda, Türkiye'nin ABD, Almanya, İngiltere ve Fransa'ya gerçekleştirdiği ihracat ile aynı ülkelerin finansal piyasaları arasında kısa dönem için pozitif ve istatistiksel olarak anlamlı bir ilişki olduğu görülmektedir.

Model kapsamında kısa dönemde, ABD, Almanya, İngiltere ve Fransa'nın finansal piyasalarının getirilerindeki bir artış Türkiye'nin bu ülkelere gerçekleşen ihracatı üzerinde pozitif yönde etki oluşturmaktadır.

Çalışma kapsamında tahmin edilen sırasıyla ARDL $(12,12)$, ARDL (12,12), ARDL (12,9) ve ARDL $(12,3)$ modellerinin kararlılıklarını görebilmek amacıyla, bir başka ifade ile yapısal değişim olup olmadığını ortaya koyabilmek için CUSUM ve CUSUM-of-Square testleri gerçekleştirilmiştir. Elde edilen ARDL $(12,12)$, ARDL $(12,12)$, ARDL $(12,9)$ ve ARDL (12,3) modellerine ait tahmin sonuçları Şekil 2'de gösterilmektedir. 
Şekil2.CUSUM ve CUSUM of Squares Test Sonuçları

DIHRABD - GDJ / ARDL $(12,12)$

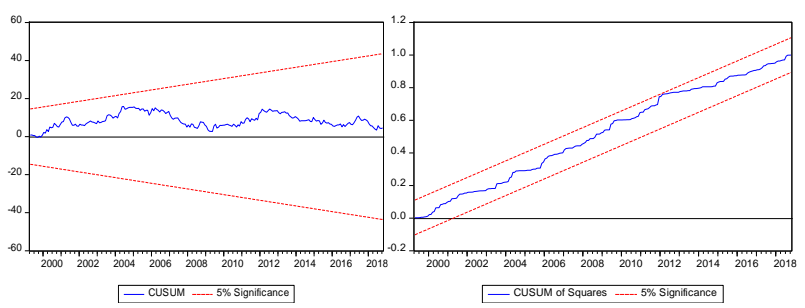

DIHRALM - GDAX / ARDL (12,12)

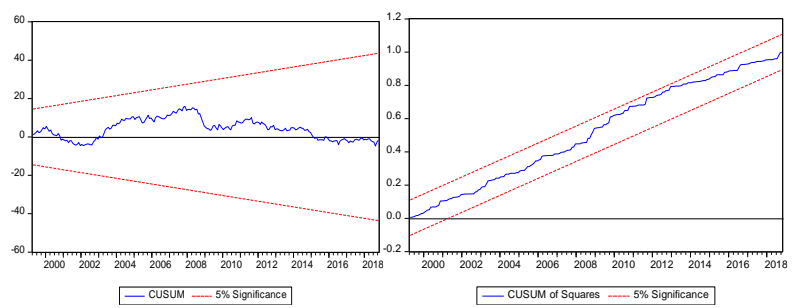

DIHRING - GFTSE / ARDL (12,9)

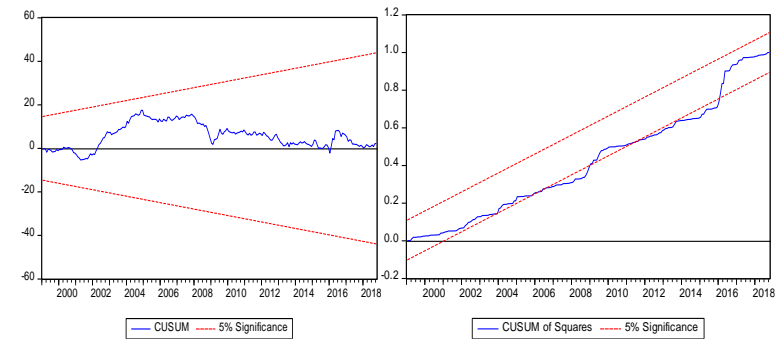

DIHRFRA - GCAC / ARDL $(12,3)$

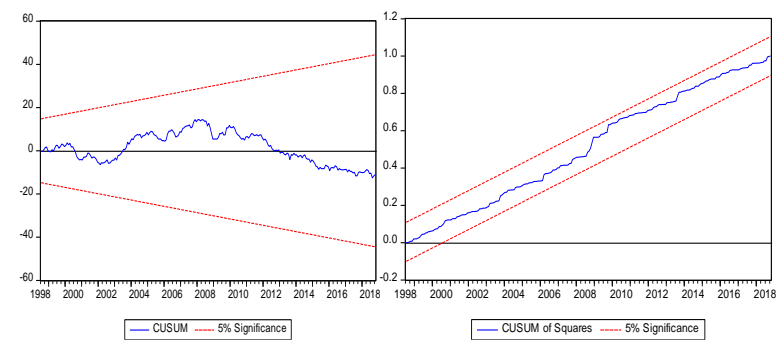

Şekil 2'de CUSUM ve CUSUM of Squares test sonuçları görülmektedir. Test sonuçlarına göre, tahmin edilen ARDL $(12,12)$, ARDL (12,12), ARDL (12,9) ve ARDL (12,3) modellerinin tahmini gerçekleştirilen dönemde kararlı oldukları ve herhangi bir yapısal kırılmanın bulunmadığ görülmektedir.

\subsection{Granger Nedensellik Testi}

Model dâhilindeki değişkenler arasında uzun dönemde bir ilişkinin tespit edilmesinden sonra, değişkenler arasındaki nedensellik ilişkisi test edilecektir. Engle ve Granger (1987)'a göre, değişkenler arasında uzun dönemli bir ilişkinin olması en azından tek yönlü bir nedensellik ilişkisinin de bulunabileceği anlamı taşımaktadır. Granger nedensellik testi gerçekleştirilirken aşağıdaki iki denklem kullanılmaktadır;

$$
\begin{aligned}
& Y_{t}=\beta_{0}+\beta_{1} Y_{t-1}+\cdots+\beta_{p} Y_{t-p}+\theta_{1} Z_{t-1}+\cdots+\theta_{p} Z_{t-p}+u_{t} \\
& Z_{t}=\beta_{0}+\beta_{1} Z_{t-1}+\cdots+\beta_{p} Z_{t-p}+\theta_{1} Y_{t-1}+\cdots+\theta_{p} Y_{t-p}+e_{t}
\end{aligned}
$$

Tablo 9'da, model kapsamında hesaplanan gecikmeli değerlere göre gerçekleştirilen Granger nedensellik testi sonucunda tespit edilen nedensellik ilişkileri ve yönleri ortaya koyulmuştur.

Tablo 9.Granger Nedensellik Test Sonuçları

\begin{tabular}{cccc}
\hline $\begin{array}{c}\text { Nedensellik } \\
\text { Yönü }\end{array}$ & $\begin{array}{c}\text { Gecikme } \\
\text { Değerleri }\end{array}$ & F-Değeri & $\begin{array}{c}\text { Olasılık } \\
\text { Değeri }\end{array}$ \\
\hline GDJ $\rightarrow$ DİHRABD & 2 & 3.5454 & $0.0302^{* *}$ \\
\hline GDAX $\rightarrow$ DİHRALM & 1 & 3.6124 & $0.0584^{*}$ \\
\hline DİHRİNG $\rightarrow$ GFTSE & 2 & 2.9062 & $0.0564^{*}$ \\
\hline
\end{tabular}

Not: - ***,** ve * sirası ile $\% 1, \% 5$ ve $\% 10$ seviyesinde anlamlılığ ifade etmektedir.

Nedensellik testi sonuçları incelendiğinde; ABD finansal piyasalarından (Dow Jones) Türkiye'nin ABD'ye gerçekleştirdiği ihracata doğru; Almanya finansal piyasalarından (Dax) Türkiye'nin Almanya'ya gerçekleştirdiği ihracata doğru; Türkiye'nin İngiltere'ye gerçekleştirdiği ihracattan İngiltere finansal piyasalarına (FTSE100) doğru tek yönlü bir nedensellik ilişkisi tespit edilmiştir. Türkiye'nin Fransa'ya gerçekleştirdiği ihracat ile Fransa'nın finansal piyasaları arasında herhangi bir nedensellik ilişkisine rastlanılmamıştır.

\section{Sonuç}

Çalışmada öncelikle Türkiye'nin ABD, Almanya ve İngiltere'ye gerçekleştirdiği ihracatın değişim oranı ile ABD (Dow Jones), Almanya (Dax), İngiltere (FTSE100) ve Fransa (CAC40) finansal piyasalarının getiri oranları arasındaki ilişki ARDL sınır testi ile analiz edilmiştir. Gerçekleştirilen sınır testi analizine göre, Türkiye'nin ABD, Almanya, İngiltere ve Fransa'ya gerçekleştirdiği ihracatın değişim oranları ile aynı ülkelerin finansal piyasalarının getiri oranları arasında eşbütünleşme ilişkisinin bulunduğu tespit edilmiştir. Eşbütünleşme analizi sonrasında, model kapsamındaki değişkenler arasındaki nedensellik ilişkisinin tespiti amacıyla Granger nedensellik analizi gerçekleştirilmiştir. Granger nedensellik analizi sonuçlarına göre; ABD finansal piyasalarından (Dow Jones) Türkiye'nin ABD'ye gerçekleştirdiği ihracata doğru, Almanya finansal piyasalarından (Dax) Türkiye'nin Almanya'ya gerçekleştirdiği ihracata doğru ve Türkiye'nin İngiltere'ye gerçekleştirdiği ihracattan İngiltere finansal piyasalarına (FTSE100) doğru tek yönlü bir nedensellik ilişkisi tespit edilirken, Türkiye'den Fransa'ya gerçekleştirilen ihracat ve Fransa'nın finansal piyasaları (CAC40) arasında herhangi bir nedensellik ilişkisi bulunamamıştır.

Çalışmada, sosyonomik yaklaşım kapsamında ülkelerin uluslararası ticaretleri ile finansal piyasaları arasındaki ilişki incelenmiştir. Çalışmada sosyonomik yaklaşım kapsamında finansal piyasalar ülkelerin sosyal ve küresel ruh halinin göstergesi olarak ele alınmıştır. Bu doğrultuda, ülkelerin sosyal ruh hallerinin uluslararası ticaretleri ile olan ilişkisi sınanmıştır. Gerçekleştirilen analizler sonucunda, ülkelerin uluslararası ticaretlerindeki değişim oranları ile ekonomik anlamda sosyal ruh hallerinin göstergesi olan finansal piyasalarının getiri oranları arasında hem eş bütünleşme hem de nedensellik ilişkisi tespit edilmiştir. $\mathrm{Bu}$ doğrultuda, ülkelerin uluslararası ticaretleri ile sosyal ruh hallerinin bir göstergesi olan finansal piyasaları arasında kısa ve uzun dönemli ilişkilerin bulunduğu görülmüştür. Ayrıca buna ek 
olarak, ülkelerin uluslararası ticaretleri ile finansal piyasalarının nedensel bir ilişki barındırdığı ortaya koyulmuştur.

Uluslararası ticaret ile ülkelerin finansal piyasaları arasında tespit edilen ilişkiler sonucunda, ülkeler arasındaki ticaretin yönlendirilmesinde finansal piyasaların sosyonomik yaklaşım kapsamında ülkelerin sosyal ruh hali olarak ele alınarak kararlar alınmasının mümkün olduğu tespit edilmiştir. Ülkelerin finansal piyasalarının gidişatına bakılarak, başka bir ifade ile ülkelerin sosyal ve küresel ruh halleri tespit edilerek olası uluslararası ticari ilişkilerin kurulabileceğine ya da sürdürülebilirliğine karar verme imkânı olduğu ortaya koyulmuştur. $\mathrm{Bu}$ doğrultuda, ülkelerin ekonomik ve finansal durumlarının uluslararası ticaretlerinin devamlılığ ya da yeni ticari ilişkilerin kurulması açısından önemli bir gösterge olduğu tespit edilmiştir.

Çalışma kapsamında Türkiye'nin ticari ilişki içerisinde olduğu ABD, Almanya, İngiltere ve Fransa'nın finansal piyasalarının Türkiye'nin ilgili ülkelere gerçekleştirdiği ihracat düzeyleriyle olan ilişkisi analiz edilmiş ve elde edilen bulgular doğrultusunda gerçekleştirilen çalışmanın ileriki araştırmalarda uluslararası ticarette hedef olarak belirlenen ülkelerin piyasaları ile olan ilişkilerinin incelenmesi suretiyle genişletilmesi faydalı olacaktır.

\section{Kaynakça}

Atwater, P. (2013).Moods and Markets. New Jersey: FT Press.

Can Kamber, S. (2018). Davranışsal İktisat Ve Rasyonellik Varsayımı: Literatür İncelemesi. Ekonomi ve Yönetim Araştırmaları Dergisi, 7(1), 168-198.

Casti, J. L. (2010).Mood Matters. New York: Copernicus Books.

Balkanlı, A. O. (2002). Küresel Ekonominin Belirleyici

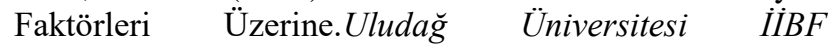
Dergisi,21(1), 13 - 26.

Dickey, D. A. \& Fuller, W. A. (1981). Likelihood Ratio Statistics for Autoregressive Time Series with a Unit Root.Econometrica,49, 1057 - 1063.

Engle, R. F. \& Granger, C. W. J. (1987). Co-Integration and Error Correction: Representation, Estimation and Testing.Econometrica, 55(1), 251-276.

Fama, E. F. (1965). Random Walks in Stock Market Prices.Financial Analysts Journal, 21(5), 55 - 59.

Fama, E. F. (1969). Efficient Capital Markets: A Review of Theory and Empirical Work.The Journal of Finance, 25(2), $383-417$.

Galeotti, F. \& Karakostas, A. (2010). The Promise of Behavioural Economics. Norwich Economic Papers, University of East Anglia, UK.

Green, M. K. (2002). R.N. Elliott's Fundamental Challenge to Mechanistic Social Models. Editör: Robert R. Prechter, In Market Analysis for the New Millennium, 9-19.

Gujarati, D. N. (2004).Economics Basic Econometrics, Mcgraw Hill.
He, F., Hu, Z.,Zhang, W.,Chai, L.,Cai, G.\&Aoyagi, K. (2017). Construction and Evaluation of Two Computational Models for Predicting the Incidence of Infuenza in Nagasaki Prefecture, Japan.Scientific Reports,7(1), $1-9$.

Just, D. R. (2013).Introduction to Behavioral Economics, USA: Wiley.

Kwiatkowski, D., Phillips, P.C.B., Schmidt, P.\& Shin, Y.(1992). Testing the Null Hypothesis of Stationarity Against the Alternative of a Unit Root.Journal of Econometrics, 54, 159 - 178.

Mitroi, A. \&Oproiu, A. (2014). Behavioral Finance: New Research Trends, Socionomics and Investor Emotions.Theoretical and Applied Economics, 21(4), 153 -166 .

Nofsinger, J. R. (2005). Social Mood and Financial Economics.Journal of Behavioral Finance, 6(3), 144 160.

Olson, K. R. (2006).A Literature Review of Social Mood.Journal of Behavioral Finance, 7(4), 193 - 203.

Parker, W. D. \&Prechter, R. R. (2005). Herding: An Interdisciplinary Integrative Review from a Socionomic Perspective.International Conference on Cognitive Economics, August 5-8, Sofia, Bulgaria.

Parker, W. D. \& Prechter, R. R. (2006). The Socionomic Theory of Finance and the Institution of Social Mood: Pareto and the Sociology of Instinct and Rationalization.Conference of the Association for Heterodox Economics, London, United Kingdom. July 14-16.

Parker, W. D. (2006). Methodological Individualism vs. Methodological Holism: Neoclassicism, Institutionalism and Socionomic Theory.Congress of the International Association for Research in Economic Psychology and the Society for the Advancement of Behavioral Economics, Paris, France. July 5-8.

Pesaran, M. H., Shin, Y. \& Smith, R.J. (1999). Bounds Testing Approaches to the Analysis of Long-run Relationships.Cambridge Working Papers in Economics 9907, Faculty of Economics, University of Cambridge.

Pesaran, M. H., Shin, Y. \& Smith. R. J. (2001). Bound Testing Approaches to the Analysis of Long Run Relationships.Journal of Applied Econometrics, 16, 289 326.

Prechter, R. R. (2001). Unconscious Herding Behavior as the Psychological Basisof Financial Market Trends and Patterns.The Journal of Psychology and Financial Markets, 2(3), 120 - 125.

Prechter, R. R. (2002).Conquer the Crash.New Jersey: John Wiley \& Sons.

Prechter, R. R. (2009).The Wave of Principle of Human Social Behaviour and New Sciences of Socionomics.Gainesville: New Classics Library.

Prechter, R. R. \& Parker, W. D. (2007). The Financial/Economic Dichotomy in Social Behavioral Dynamics: The Socionomic Perspective.The Journal of Behavioral Finance, 8(2),84 - 108. 
Shiller, R. J. (1984). Stock Prices and Social Dynamics.Brookings Papers on Economic Activity, 2, 457 -510 .

Shiv, B., Loewenstein, G., Bechara, A., Damasio, H. \& Damasio, A. R. (2005). Investment Behavior and the
Negative Side of Emotion.Psychological Science, 16(6),435 - 439 .

Turan, Z. \& Öztürk, Y. K. (2016). Keynes Sistemi Ve Bekleyişlerin Sisteme Katkısı. Niğde Üniversitesi İktisadi ve İdari Bilimler Fakültesi Dergisi, 9(2), 259 - 269. 